\title{
CORRIGENDUM
}

\section{microRNA-10b enhances pancreatic cancer cell invasion by suppressing TIP30 expression and promoting EGF and TGF- $\beta$ actions}

H Ouyang, J Gore, S Deitz and M Korc

Oncogene (2017) 36, 4952; doi:10.1038/onc.2017.190; published online 12 June 2017

Correction to: Oncogene (2014) 33, 4664-4674. doi: 10.1038/ onc.2013.405; published online 7 October 2013.

Since the publication of the above article, the authors noted that they had neglected to report that cel-miR-39 had been used to adjust for RNA extraction efficiency, and that only 10 normal

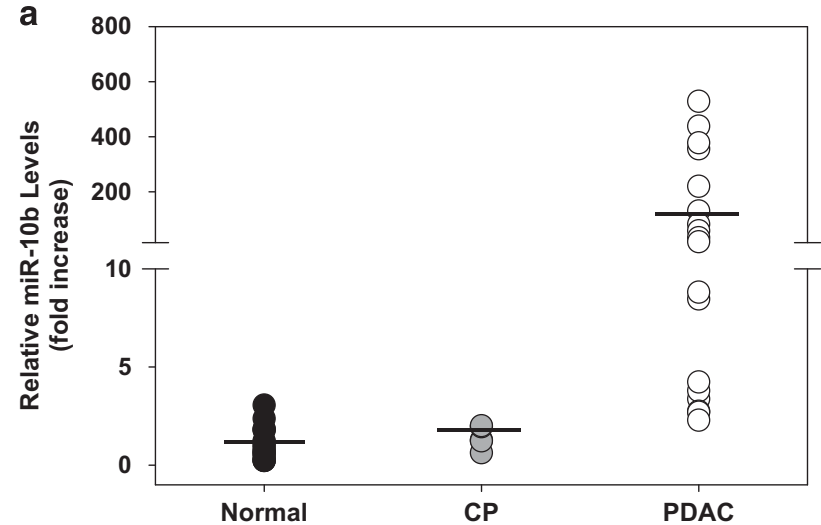

Figure 1. (a) Plasma miR-10b levels. Compared with plasma from normal controls $(n=18$; closed circles) and chronic pancreatitis patients (CP; $n=5$; gray circles), miR-10b levels were significantly elevated $(P=0.002$ and $P=0.067$, respectively) in the plasma of PDAC patients ( $n=18$; open circles). Horizontal bars denote mean levels. For each sample, $3 \mu \mathrm{l}$ of a $5 \mathrm{~nm}$ cel-miR-39 oligonucleotide stock were added to $100 \mu \mathrm{l}$ of plasma. RNA was then isolated with TRlzol LS Reagent, and 10 ng of RNA per reaction was converted to cDNA using the TaqMan MicroRNA Reverse Transcription Kit, and TaqMan primers for hsa-miR-10b, hsa-miR-16 and cel-miR-39. qRTPCR was performed using the ViiA7 as described in Methods. Ct values for hsa-miR-10b were normalized to cel-miR-39 spike-in recovery, then to the internal reference (hsa-miR-16), yielding the $\mathrm{dCt}$. The average $\mathrm{dCt}$ for the normal samples was then subtracted from each individual $\mathrm{dCt}$ for miR-10b, yielding the $\mathrm{ddCt}$ value. Fold increases were calculated relative to miR-10b levels in normal control plasma. samples and 17 pancreatic cancer samples were used to carry out the calculations.

Provided below is the revised Figure 1a and a revised figure legend to rectify these issues.

The authors would like to apologize to the readers for any inconvenience this may have caused. (c) (1)(2)(2) This work is licensed under a Creative Commons Attributioncc) ${ }_{\mathrm{BY}} \mathrm{NC}$ SA NonCommercial-ShareAlike 4.0 International License. The images or other third party material in this article are included in the article's Creative Commons license, unless indicated otherwise in the credit line; if the material is not included under the Creative Commons license, users will need to obtain permission from the license holder to reproduce the material. To view a copy of this license, visit http:// creativecommons.org/licenses/by-nc-sa/4.0/

(c) The Author(s) 2017 